\title{
Sønderjyske slots- og herregårdshaver
}

Et supplement

\author{
Af Peter Kr. Iversen
}

I to afhandlinger i Sønderjyske årbøger 1927 og 1929 har Johannes Tholle skildret sønderjyske herregårdshaver. På fastlandet omtales haverne på Gråsten, Schackenborg og Hansborg, medens han ikke er opmærksom på det store parkanlæg på Gram, ligesom han ved skildringen af de alsiske slotsog herregårdshaver har givet de store anlæg og planteskoler på Nordals en stedmoderlig behandling.

Gram slotshave eller park havde virkelig fortjent at få et par linier med på vejen. Grevinde Sophie Dorothea Schack, født Marschalk (1656-1707), var meget haveinteresseret, og der fandtes på Gram i slutningen af 1600-årene både en lille og en stor have, og den sidste var ikke blot noget ganske særligt for den nordslesvigske egn, men for hele landet. En engelsk rejsende, som i 1702 besøgte Gram beretter således om den, at der med stor kunst var anlagt terrasser, lavet vandfald i flere afsæt og springvand eller fontæner. For enden af midteralléen var bygget en salon med grotte "på italiensk vis med brogede vinduer «. Indvendig var salonen prydet med deviser og emblemer, på loftet var der malet et øje som symbol på forsynet. Haven var forbundet med Lunden med en allé, kaldet "Promenaden«, og Lunden blev gjort til en lystskov. Selve slotssøen var naturligvis også inddraget i anlægget. Her havde grevinden fået placeret en robåd, der var så stor, at den kunne rumme et spisebord til 20 personer.'

Også på Schackenborg viste grevinde Sophie Dorothea sin store interesse for havekunsten. Omkring 1696 fik hun her anlagt den store have syd for alleen. ${ }^{2}$ Denne have, "Sønderhaven « blev i tidens løb omlagt adskillige gange, 1765 således til fransk stil, som det kan ses af stikket i Pontoppidans Danske Atlas. Et par år senere, da ladebygningerne m.v. var nedrevet, anlagdes her øst for slottet nord for alleen en stor køkken- og frugthave. ${ }^{3}$ 


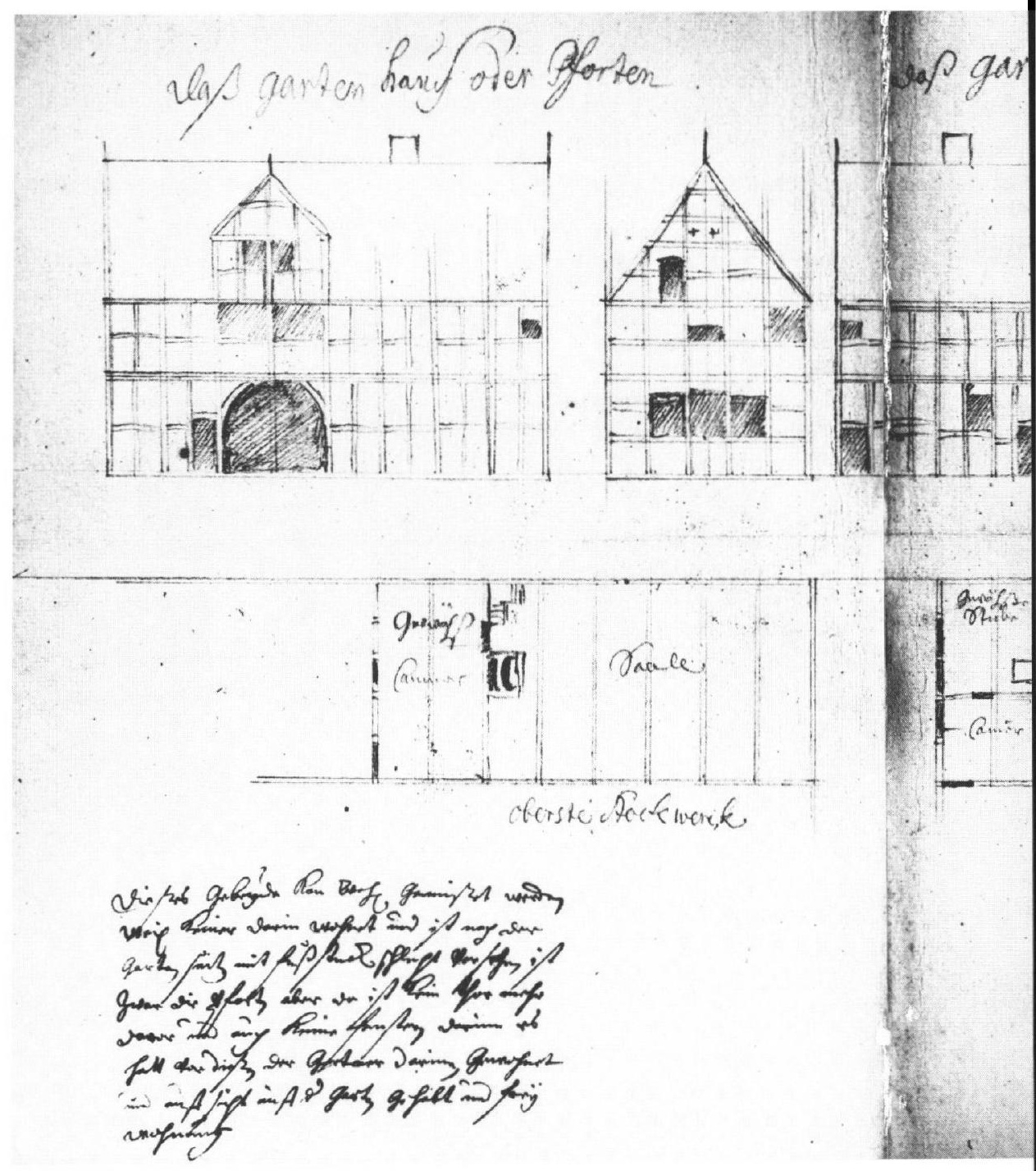



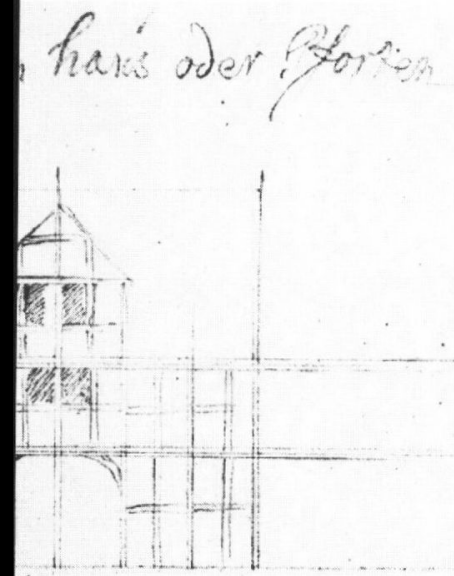

$+$

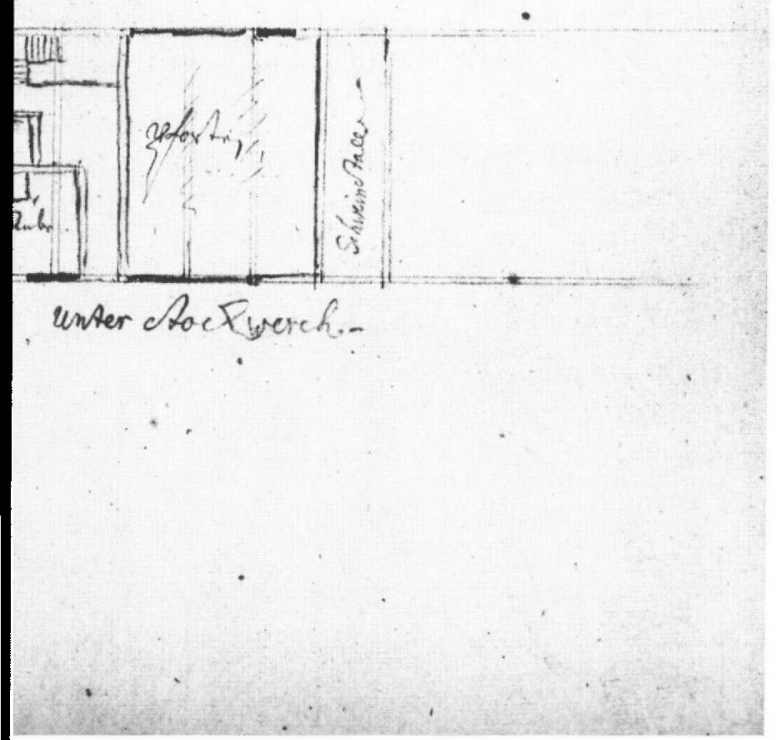

Kombineret gartner- og porthus på Gammelgârd. Der findes beskrivelser, men ingen tegninger af gartnerboligerne på Nordhorg og Dsterholm. Fra Gammelgärd findes derimod rodkridts- og blyantstegninger af et noget mindre garmerhus, der samtidig var porthus, Af blyantstegninger gengives her planerne for stueetage og forste sal samt nordfacaden. I en ledsagende tekst oplyses, at bygningen, da den blev tegnet ca. 1650, var meget forfalden. T.v. for den 5 alen brede port er der $i$ stueetagen en indgangsdor, hvorfra en smal gang forer hen til et kokken med åbent ildsted. Herfra går der bilaggerovne ind til en stue og til et "vakstrumw. Endvidere er der i stueetagen et uopvarmet rum. Fra kokkenet forer en trappe op til 1.sal, hvor der ligeledes langst t.v. er et "vakstrum", der kan opvarmes ved en kamin placeret $i$ den seks fag store "salk, der nappe udelukkende kan have varet anvendt til gartnerens private selskahelighed, men vel ogsà til overvintring af sarte planter. I loftsetagen har der varet et par kamre. Til hojre for porten har der $i$ stueetagen varet svinestald. Den otte fag lange bygning er opfort $i$ bindingsvark. Andre samtidige tegninger fra Gammelgård er gengivet i Sonderjyske Arboger 1949 s. $102 f f$. og i Sonderjysk Månedsskrift 1988 s. 170.

Sonderborg amtsarkiv. Sager vedr. Gammelgård II; nr. 192. 


\section{Tidlige alsiske haver}

Fra hertug Hans d. Yngres (d. 1622) tid har der givetvis også været betydelige haveanlæg ved hans alsiske slotte, men kilderne er forbavsende tavse herom. Fra Sonderborg vides, at han på sine gamle dage har søgt at anlægge en vingård der, ${ }^{4}$ og det skulle derfor være mærkeligt, om denne initiativrige mand ikke også har anlagt større eller mindre haver i det nordalsiske. I hvert fald kan det af inventarier fra første halvdel af 1700-årene ses, at en del af de ældste træer må stamme langt tilbage i 1600-tallet, sandsynligvis tilbage til Hans d. Yngres tid, men det er dog efterkommerne, der for alvor foretager de store haveanlæg ved Nordborg, Østerholm og på Als' nordspids ved Augustenhof eller Augustgård, som den i 1700-tallet benævnes i arkivalske kilder. Man har tidligere tillagt Peter Vothmann, d. 1736, æren for at have anlagt den forste alsiske have og planteskole ved Sønderborg slot, ${ }^{5}$ men dette må dog siges at være en sandhed med modifikation. Han overtog 1695 den sonderborgske slotshave i forpagtning, men allerede ca. 1680 havde hertug August (d. 1699) efter Nordborg slots brand omdannet den gamle slotsplads og anlagt en have. ${ }^{6}$ Hvem der har ståt for anlæggelsen vides ikke, men i den nordborgske kirkebog nævnes en unavngiven "moere«, dvs. neger, der døde 1684. Han var gartner og tjente hos amtmanden. Han kan i hvert fald have medvirket ved anlæggelsen. På denne tid må imidlertid den store frugthave syd for slottet allerede have eksisteret - $\mathrm{i}$ hvert fald til dels. Hertug August må i det hele taget have haft ganske særlige interesser for haveanlæg; foruden det betydelige haveanlæg ved den af ham oprettede lystgård Augustenhof eller Augustgård indlagde han sig også fortjenester ved haverne og planteskolen på Østerholm.

Men også på Gammelgård i Ketting sogn var der tidligt et betydeligt haveanlæg, som kan være anlagt af hertug Hans den Yngre, måske af sønnen Alexander eller dennes enke Dorothea, der døde 1639. Af en rødkridtstegning fra ca. 1650 af Gammelgård og dens omgivelser fremgår, at der syd og vest for slottet har været betydelige haveanlæg, som går ned til Mjang dam, og som i hvert fald til dels var omgivet af et hegn. Af et notat i Ketting kirkebog ses, at der har været en »krudgård «, d.v.s. køkkenhave, men der har også været mange træer og en stor prydhave. ${ }^{7}$ Haven skulle 1669 kunne give en indtægt på op til 30 rdlr., men fraregnes gartnerens løn giver haven underskud. Den er da også, som det hedder, mest anlagt "zum plaicir«. Arbejdet i haven blev i øvrigt udført af hovpligtige kådnere. På en høj imellem slottet og søen var der på denne tid et lysthus, og gartnerboligen, hvori der var vakstrum, var kombineret med den nordre portbygning. ${ }^{8}$

Denne store have gik i 1700-årene i forfald og blev 1742 overladt til forpagter Hans Petersen, der omdannede den til almindelig agermark. Nic. Fr. Broder- 


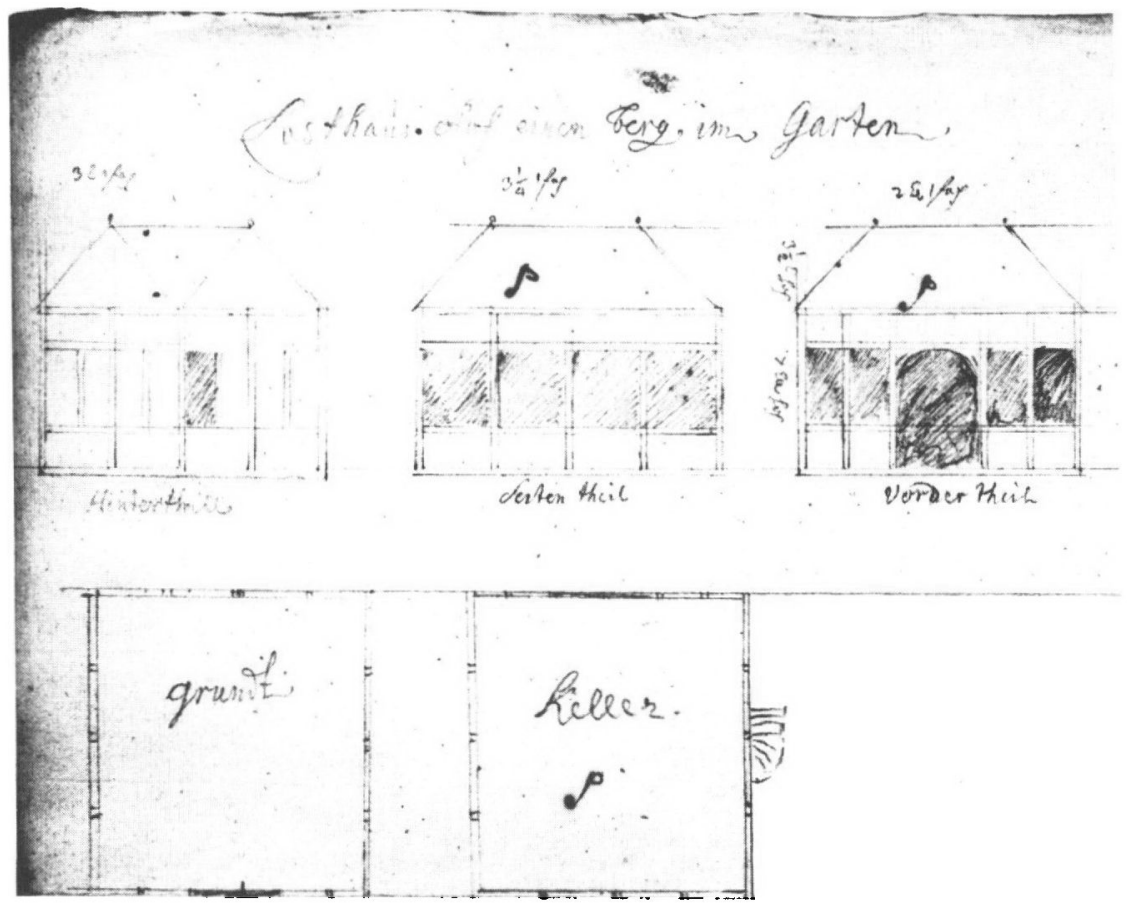

Lysthus i Gammelgards have. Lysthuset stod sydvest for slottet pả et "hijt hjerg", altsâ en hoj, hvorfra der har varet udsigt over park og landskab. Huset var 6 fug langt og 4 alen hredt, opfort $i$ hindingsvark med hraddetavl. Det var $101 \%$ alen hojt, og der synes at have varet ovenlysvinduer $i$ et todelt tag, maske kombineret med en hvalving. De midterste to fag var ábne ud mod haven, og det hertugelige herskab har her kunnet sidde beskyttet mod sol og blast. Trahlghingen var opfort over en hvalvet kalder, hvortil der var en udvendig nedgang. Bygningen var ca. 1650 rädden og forfalden.

Sonderborg amtsarkiv. Gammelgård II nr. 192.

sen, der var forpagter fra 1749 , lod derefter ved hjælp af hovfolk anlægge en have på det gamle slots byggetomt. Der var her et lysthus og en hvælvet kælder samt nogle store sten, rester fra det nedbrudte slot. ${ }^{9}$ En egentlig slotshave kan der dog næppe mere være tale om, og en fast gartner er ikke mere på lønningslisten.

\section{Nordborg slotshave}

Omkring 1700 begynder oplysningerne om de nordborgske haver at flyde rigeligere. Lige efter århundredskiftet oplyses, at forpagter Chr. Ernst Frobøse fra ladegården årligt skulle levere 50 læs gødning til slotshaven, hvilket jo i 
hvert fald mere end antyder, at haven må have haft en ganske anselig størrelse. Omkring 1720 har en gartner ved navn Franz Rademacher forestået det store haveanlæg, og han får 1725 fornyet sin ansættelse af hertug Friedrich Carl. I hans ansættelsesbrev hedder det, at han skal sørge for at holde jorden godt gødet, at hækkene bliver klippet, og at gangene bliver holdt rene. Hvad der er nok så interessant, er oplysningen om, at han med hensyn til køkkenurter skulle sørge for, at der til skiftende årstider var så mange som muligt. Der skulle være gode forråd af frugt, kål, roer, gulerødder, selleri, porrer og lignende, så at det hertugelige køkken havde tilstrækkelige forsyninger hele vinteren. Han skulle endvidere sørge for alle slags frø, således at man såvidt muligt kunne være selvforsynende. Mistbedene skulle holdes $\mathrm{i}$ orden, især skulle der drages omsorg for, at vinduerne var i orden, og han skulle holde »et flittigt øje« med orangeriet, hvor der var »louners«, oranger og rosmarin, samt andre træer og vækster, der skulle kunne overvintre i god stand. Forår og efterår skulle han sørge for, at de blev anbragt i de dertil bestemte væksthuse, og hertil ville han få anvist fornøden hjælp fra hovpligtige undersåtter. Det var gartnerens pligt at føre tilsyn med de nye plantager, hvor udgåede træer skulle udskiftes med unge, sunde, og i planteskolen skulle alle slags træer fremavles. Et ikke nærmere bestemt kvantum gødning skulle leveres fra ladegårdens stalde. I øvrigt fik han til arbejdets udførelse som hidtil anvist hoveripligtige kådnere. Redskaber kunne han kun anskaffe efter indhentet tilladelse. Gartnerens årlige løn og kostpenge var fastsat til 80 rdlr. cour. årl., hvortil dog kom græsning i haven samt affald fra træerne. ${ }^{9 a}$

Haverne må have været $i$ ganske god stand og have givet et rimeligt udkomme, thi ved Franz Rademachers død 1733 overtog amtmand over Sønderborg og Nordborg amter Holger Scheel selv forpagtningen af dem. I amtmandens forpagtningskontrakt oplyses, at 8 kådnere hver skulle yde hoveri to dage ugentligt, og at der skulle leveres 50 læs gødning fra ladegården. Amtmanden fik ret til græsning af to køer på ladegårdsmarkerne, og til gengæld skulle han vedligeholde gartnerhus og stalde. Ved forpagtningens ophør skulle have, orangehus, mistbænke og vinduer, samt frugttræer, planteskole, andre forhåndenværende vækster og redskaber afleveres i samme tilstand, hvori de var overtaget. For hele herligheden skulle betales en årlig afgift på 12 rdlr. cour. Amtmanden har naturligvis ikke selv passet gartneriet eller boet $i$ gartnerhuset. Han må enten have haft en gartner ansat som bestyrer, eller også har han haft en underforpagter. Men herom synes kilderne at tie.

Af det nævnte inventarium fra 1733 får man et ganske godt indtryk af det store haveanlæg syd for slottet, men der kan desværre på grundlag af beskrivelsen ikke udarbejdes en regulær tegning. Haven var mod vest hegnet, mod syd af en mur af marksten og mod nord af et plankeværk af fyr. På havens 
nordside var der på begge sider af drivhuset, som altså må have ligget i selve hegnet, som en del af dette, et plankeværk. Mod øst var der et 41 fag langt plankeværk og en mur af marksten. Der er ikke nævnt noget hegn mod syd.

Et gartnerhus, hvis beliggenhed ikke er nærmere angivet, må formentlig have ligget i nærheden af drivhuset længst mod nord. Det var 15 fag langt og 4 fag bredt. På husets vestside var tilbygget et såkaldt vaksthus, der var fire fag langt og fire fag bredt. På sydsiden var der et fuglehus, ligeledes fire fag på begge led. I gartnerhuset var der en dagligstue med jernkakkelovn, en pisel, et børne- og drengekammer, køkken, spisekammer og et bagehus med bageovn. Efter tidens forhold har gartneren boet ganske komfortabelt.

Drivhuset, der som nævnt lå helt nord $\mathrm{i}$ haven og her udgjorde en del af hegnet, var fem fag langt og fire fag bredt. Det havde store glasruder, men en del var dog 1733 enten skårede eller manglede helt. På hver side af drivhuset var der to mistbænke, hvor også en del af ruderne manglede.

Foruden disse faste anlæg beskrives også detaljeret havens vakster. Vi får oplyst, at på hver side af gartnerhuset var der en lille lysthave, hvor der stod to tax og var anlagt et par blomsterbede. Der var tre hovedgange, en der fulgte det vestre hegn, en det østre og en midtergang. Foran den vestre gang var der mod syd en grøn- og hvidmalet port. Endvidere var der i det østre hegn en port, foran hvilken der var inddraget noget jord til haven, og her var plantet 15 unge lindetræer. Her på østsiden uden for hegnet var der også en lindeallé bestående af 87 unge træer, men om denne er gået nord-syd eller østvest, fremgår ikke klart, men formentlig vest-øst. På hver side af den nordsydgående vestlige hovedgang, var der lave, klippede ligusterhække.

Der var et par damme i den store have, og endvidere midt i den en gammel forfalden brønd sat af marksten. Til den sydligste dam førte fra den vestlige hovedgang en nøddegang af vilde hassel. Her var der på dammens vestside en lille planteskole med 260 podede og en del upodede abletræer. Endvidere stod der her 12 hestekastanier og 32 små lindetræer. I hasselhækken stod der 6 store, gamle lindetræer og et valnøddetræ. På dammens østside var der en klippet ligusterhæk, og fra dammen, hvori der ikke var fisk, og »helt ud«, men ikke angivet i hvilken retning, dog snarest mod øst, var der en gang, som på begge sider havde en hæk med høje hegnsbøge. En anden gang, der gik fra "gangporten« og til den østre port, havde på begge sider hække bestående af liguster- og stikkelsbærbuske.

Den midterste gang førte fra drivhuset længst mod nord $\mathbf{i}$ haven til en andedam. Denne gang var ligeledes hegnet af klippede ligusterhække, hvori der stod 85 unge hestekastanier. Den østre gang var en allé af 18 fod høje, klippede hegnsbøge, og det samme var tilfældet med en søndre gang. Andedammen var omgivet af et 40 fag langt hvid- og rødmalet stakit, og omkring 
den stod endvidere 36 unge lindetræer. Mellem de to damme var der en forbindelsesgang, som altså ikke skulle være identisk med den ovennæunte midtergang. Den var hegnet af 16 fod høje klippede bøge.

Der var i øvrigt mange mere eller mindre sjældne vækster i den store have eller park. I drivhuset var der f.eks. sydlandske træer og buske. Der opregnes seks ferskentræer, fire abrikostræer, 12 vinstokke og 6 kvædebuske. I selve haven taltes 73 kirsebærtræer, 93 pæretræer, 209 æbletræer, 11 svedskeblommer, 21 almindelige blommer og to store vilde kvæder. Endvidere var der fire laurbær i hver sin kasse og to uden kasser, to stk. nerium, d.v.s. nerier, den ene i kasse, den anden i potte, to iucca gladiosa, d.v.s. palmeliljer, en myrte, en genistra hispania, d.v.s. en storblomstret gyvel, et arbor iudæ, sandsynligvis "føde-lygte«, et sedu arborea, d.v.s. tykblad eller pengetræ, en granat, d.v.s. granatæble $\mathrm{i}$ kasse med laurbær, to kasser med jasmin og 27 dårlige nellikekasser. ${ }^{10}$

Det har altså været en meget varieret bestand af træer, buske og andre planter $\mathrm{i}$ den store have, og det er helt usandsynligt, at de mange frugter har kunnet bruges $i$ den hertugelige og senere amtmandens husholdning. Der må givetvis have fundet salg sted.

Det må vel have været en ganske god forretning for amtmanden at have haven i forpagtning, idet den senere amtmand Schoubynacht 1747 også viste stor interesse for at få den overdraget på de samme betingelser, som Scheel havde fået den til i 1733."

Imidlertid må det have knebet for Schoubynacht at holde haven i god stand, idet det af Joh. Arndt Dyssels beskrivelse 1763 fremgăr, at haven på dette tidspunkt var meget forsømt. Dyssel skriver, at vejen fra Oksbøl til Nordborg

Grundplan over Nordhorg flakke med slotshaven 1781. I Erich Pontoppidans Danske Atlas bind VII findes et prospckt af Nordhorg set fra nord, hor man far indtryk af den tatte heplantning syd og sydvest for slottet. Endvidere er der her en grundplan, hvor man pa ostsiden af Okisbol vejen ser beliggenheden af den store have, der her kaldes Kongens Have. Den er ikke stodt direkte op til slotssoen. idet der er en mindre bebyggelse omkring Ostergade og Sondergade, nu henholdsvis Storegade og Lajtertoft, der har ligget mellem slot og park. Denne ma have strakt sig mod syd til omkring det nuvarende radhus. Den var pả dette tidspunkt i forfald; jfr. s. 30. Grundplanen er tegnet af H. Michelsen. Numrene pä planen er anbragt lidt tilfaldigt, og kun meget fä af gadenavnene cr sammenfaldende med de nutidige. 1) Kirken, 2) den fyrstelige bigravelse, 3) Nordhorg slot, 4) Herregürden, 5) den bombarderede mur, 6) Slotshroen. 7) Amtstuen, 8) Prastegard(en, 9) Diakonhuset, (1)) Skolen, 11) Posthus og apotek, 12) Ostergade, i dag den ostligste del af Storigade, 16) Kirsehargade, 17) Sondergyde, 18) Vestergade, 19) Kobingsgade, 20) Lillegade, 21) Kirkegärdsgyde, 22) Norregade, 23) Slotsgade, 24/ Slotssoen, 25) Molleharken, 27) Erens Port, helt mod ost for enden af davarende Ostergade, $i$ dag Storegade. I Sonderiyske Stednavne V. s.5 fejlagtigt angivet som beliggende ved landevejen til Okshol, 28) Organist- og degnehuset, 29) Polvej, 3l) Mjelswej. 32) Hagenbjargvej, der er en fortsattelse af davarende Østergade, 33) Vej til Okshal sogn. 


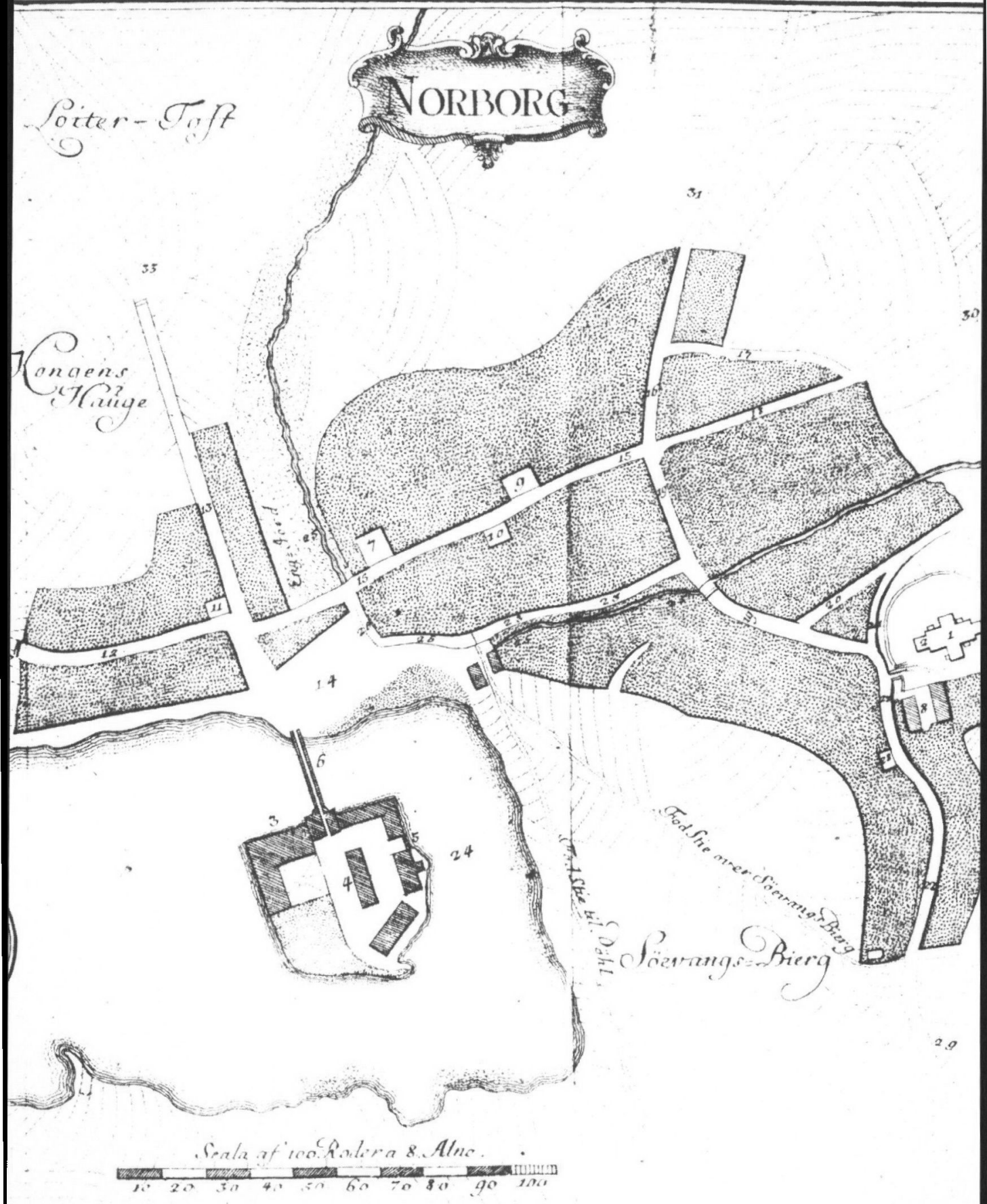


fører gennem en skov afvekslende med enge og marker, indtil man når slotshaven på højre hånd. Der begyndte en ret prægtig og bred allé, som førte lige til slottet. Alleen var gammel, da træerne var meget tykke, men de var skammeligt forhugget. Ligeledes lå den dejlige have aldeles øde og unyttig, og endvidere oplyses, at en privatmand efter sigende skulle have budt 2000 rdlr. for den, hvoraf man i nogen grad kan slutte sig til dens udstrakning. Men denne store have eller park forsvandt lige som de andre store alsiske haveanlæg. ${ }^{12}$

En af grundene til havens forfald er sikkert, at de nordborgske kådnere, der jo næsten alle var håndværkere, blev mere og mere uvillige til at udføre det forhadte hoveri i haven og selv undgik det ved at leje folk til at udføre det.

Forfaldet viste sig allerede stærkt i 1730'erne, hvor det store drivhus 1737 var så forfaldent, at det af generalbygmester Häuser foreslås afhændet til højstbydende ved en offentlig licitation. Rentekammeret giver sin tilladelse hertil 1739. Også fuglehuset var meget medtaget af tidens tand. ${ }^{13}$ Men forfaldet var dog ikke værre, end at kong Frederik V i 1750 under et ophold på Augustenborg foretog en udflugt til Nordborg for bl.a. at bese den store have. ${ }^{13 a}$

\section{Augustenhof eller Augustgård}

Der var også andre store haver på Nordals. Haven ved Augustenhof eller Augustgård ved den alsiske nordkyst $\mathrm{i}$ nærheden af fyret var ligeledes anlagt af hertug August i de sidste årtier af 1600-tallet. I den store park anlagdes en kanal, som i dens vestlige del omsluttede to kratbevoksede sneglehøje, hvor der ligesom på Østerholm avledes vingårdssnegle. ${ }^{14}$ På Augustgård var haven i $1720^{\circ}$ erne medindbefattet $\mathrm{i}$ forpagterens kontrakt, og måske har han selv drevet den eller også haft en gartner hyret. I den tid blev gartnerhuset, der var 8 fag langt og 3 fag bredt, i hvert fald meget forsømt. Køkkenet angives 1730 at være meget forfaldent efter at have været ude af brug i mange år. I 1730 fik imidlertid August Petersen udnævnelse som gartner eller urtegårdsmand, som han kaldes i kirkebogen, i Augustgårds have. I hans ansættelsesbrev oplyses, at der er et orangeri, d.v.s. et drivhus, hvis vækster han skal tage vare på, ligesom der er mistbænke og en planteskole for gavntræer. Gartneren skulle ikke have kontantløn, men får fribolig, brændsel, græsning til to køer og indtægter af havens træer og jordfrugter. Hertil kom endvidere hoveri af to kảdnere. August Petersen dør 1750, 62 år gl., og derefter kendes ikke flere gartnere eller urtegårdsmænd på Augustgård. De ovennævnte sneglehøje er ikke næunt $i$ hans ansættelsesbrev, hvilket kan tyde på, at de ikke har haft nogen økonomisk værdi på dette tidspunkt. ${ }^{15}$ 


\section{Østerholm}

På Østerholm må der allerede, medens slottet var anvendt som enkesæde for hertugslægten, have været betydelige haveanlæg, men også her viste hertug August straks ved sin tiltrædelse 1680 interesse for have og park. En af hans første handlinger var at ansætte Christian Karlsen som gartner med en årsløn på 60 rdlr. ${ }^{16}$ Til hjælp ved arbejdet $i$ haverne fik han tildelt hoveriet af seks af godsets kådnere, og om foråret skulle der leveres gødning fra hollænderiet. Stort mere ved vi ikke om de østerholmske haver, lyst-, frugt- og køkkenhaven på denne tid, men de store gamle træer, der senere omtales, må have været $\mathrm{i}$ god vækst.

Betydeligt mere ved vi om disse haver, efter at Chr. Hansen d. 16. marts 1723 fik ansættelse som gartner. ${ }^{17}$ Han var alsinger af fødsel, idet han var født i Oksbøl 1670. Desværre foreligger der ikke oplysninger om, hvor han har fảet sin uddannelse, måske har det været $i$ en af de andre store alsiske haver. Administrationen af de nordborgske godser var netop overtaget af den sønderborgske amtmand v. Platen, og af hans bestalling for "mester 4 Chr. Hansen fremgår, at han skal holde de tre haver i god orden. Jorden skulle holdes fri for kvik og andet ukrudt, træer skulle plejes, og gange holdes rene, ligesom han skulle sørge for klipningen af hækkene. Kun efter indhentet tilladelse måtte der fjernes træer eller gennemføres forandringer $i$ haverne. Gartneren skulle holde en god planteskole, således at gamle træer kunne erstattes med nye. Medens den tidligere gartner Chr. Karlsen havde fåt en fast årlig kontantløn, bestod Chr. Hansens aflønning i fribolig i gartnerhuset og fortjeneste ved salg af frugterne fra de tre haver samt ret til græsning af to køer og hovarbejde af fire kådnere, altså en reduktion på to i forhold til 1680 .

I forbindelse med Chr. Hansens overtagelse af gartnerstillingen blev der $\mathrm{i}$ juni foretaget syn, beskrivelse og inventering af de østerholmske slotshaver ved gartner på Augustenborg Peter Voetmann og husfoged Johann Gottfried Zoffmann, Sønderborg. Af de to mænds vidtløftige beskrivelse er det muligt i grove træk at danne sig et billede af havernes udseende.

Man begyndte med at se på lysthaven, som lå på østsiden af slottet. Fra syd kom man ind $\mathrm{i}$ denne have ad en solid dør eller låge. Til højre for denne var haven hegnet af et ca. 13 år gammelt plankeværk. Mod øst og nord var hegnet en mur af marksten, og mod vest ind mod slotsgraven var der et plankeværk 16 fag langt.

Lysthaven var inddelt i fire kvarterer, d.v.s. firkanter, som var omgivet af ligusterhække yderst og buksbomhække inderst. De var beplantet med alle slags almindelige blomster, og i dem stod 45 podede kirsebærtræer, 8 vilde kirsebær og 10 blommetræer. Opbundet til den nordre og østre stenmur stod 
endvidere fire abrikostræer, tre kvæde-, fire kirsebær-, seks fersken-, et pære-, et morbær- og et æbletræ. I et gammelt "Immenhaus«, som her må være en slags drivhus, stod der i ti forgyldte blomsterpotter to granatæbletræer og tre små pomeranstræer. Endvidere var der her 15 små potter med forskellige ringe vakster samt to firkantede træfade med figentræer. Midt $i$ haven var der en gammel fyrretræs pyramideagtig bygning, hvoromkring der var placeret 60 forskellige blomsterpotter med nelliker og cypresser. I lysthavens rabatter var der hist og her stikkelsbær- og ribsbuske.

På slottets sydside, altså ned mod det senere såkaldte domestikhus, lå den store frugt- og køkkenhave, som må have strakt sig i vest-østlig retning. I det nordre 15 fag lange plankeværk var der en indgangslåge, og vest for slottet var der en køreport, der førte ud til den åbne mark. Op ad plankeværket stod to porsbuske, to abrikoser, to kvæder, to kirsebær og nogle ribs- eller solbærbuske. Her var der endvidere to store mistbænke opført af sten og med brede egetræsrammer. Syd herfor var der tre firkanter kåljord, hvori der fandtes en del beskårne ribs- og stikkelsbærbuske, nogle roser samt en del frugttræer, nemlig 13 blommer, 30 podede kirsebær, 27 vilde kirsebær, en morbær og en mispel. I denne have var der to øst-vestgående hovedgange, den ene mod nord, den anden mod syd, og begge beplantet med høje hassel. Disse gange krydsedes af to andre syd-nordgående nøddegange.

Placeringen og indretningen af de omtalte to haver kan så nogenlunde klarlægges, medens de i det følgende omtalte haver vanskeligt kan stedfastes nøjere. En større frugthave, Vestergård, må efter navnet have ligget mod vest. I denne var der 120 gamle og unge æble- og pæretræer og et stort kastanietræ. Syd herfor var der en grøn plads, kaldet Strælbjærg, hvor der stod 12 gamle og unge æbletræer, et valnøddetræ og et kastanietræ. Mod øst var der en lokalitet, der hed Storkebjærg, og hvor der stod 182 æble- og pæretræer, og hvor der ligeledes var en planteskole med 180 små podede æbletræer. Fra Storkebjærg gav en låge adgang til marken. Her mod øst var der også en hovedtværgang eller -sti kaldet Bigang (eller Bienengang), som på begge sider havde et lægtehegn, og her ved eller i dette stod der 36 lav- og 14 højstammede

"Situations Charte des königlichen Pachhofes Osferholm, Ambts Norhurg Anno 1768u. Kortet er udarbejdet i forbindelse med gärdens udparcellering og viscr, hvordan jorderne hlev opdelt i nye lodder. Yderst til hojre Østersuen og vindrose, som viser retningen mod nord.

Det gamle Østerholm ses forneden i midten. Man ser den osterholmske gardsplads med bigninger (a). der har ligget vest for voldstedet og det nedhrudte slot (c). som 1768 var have. Bade gardsplads og voldsted er omgivet af en vandgrav ( $h$ ). Bogstavet (d) hetegner solgte grunde, den sakaldte store og lille have. Denne strakte sig altsa i 1768 vest, syd og ost for slottet, og det svarer til beskrivelsen i 1723. hvor de store haveanlag siges isar at have strakt sig mod ost og syd for slottet.

Rigsarkivet. Rentekammerets tyske afdeling. Foto Rigsarkivet. 


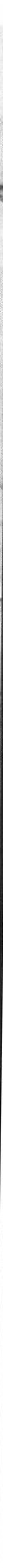


æble- og pæretræer. Endnu længere mod øst i Rosengangen var der 35 æbletræer samt et ukendt antal roser. På et areal syd for gartnerhuset var der 10 æbletræer, 6 blommetræer og 19 valnøddetræer, og langs med østmuren var der 15 vilde kirsebærtræer og tre kvæder. Herfra mod syd var en indhegnet frugthave med 58 æbletræer, syv valnød-, tre kirsebær- og to blommetræer. Tæller man frugttræerne sammen, når man til det resultat, at der i de østerholmske haver har været 469 æble- og pæretræer samt 180 små podede æbletræer i planteskolen. Af podede kirsebær var der 84, af upodede 40 , af blommer 31, af morbær 2, af kvæder 8, af abrikoser 6, af ferskener 6, af figen 2, af pors 2. af valnød 27, af mispel 1 , af granat 2 og pomerans 3 . Hertil kommer et ukendt antal hassel-, stikkelsbær- og ribsbuske. Selv om der har været en stor husholdning på Østerholm, ladegården indbefattet, har det været helt umuligt, at man her har kunnet bruge frugterne selv. Der må givetvis have fundet et stort salg sted. Omegnens bønder og kădnere har i planteskolen kunnet hente træer til plantning i egne haver og langs med vejene.

Indtægterne fra salget af frugterne fra de østerholmske haver og planteskoler tilfaldt som nævnt gartner Chr. Hansen, og fortjenesten har sikkert været ganske god. Han var som nævnt 53 år, da han 1723 overtog gartneriet i forpagtning. men som årene gik, synes han at have haft lidt vanskeligt ved at passe de store haveanlæg. I hvert fald gav en gartner Andreas Hansen fra København 1741 udtryk herfor. Han ville af brødnid gerne selv overtage haverne og skildrede derfor over for myndighederne haverne som ruineret, bl.a. skulle gartnerhuset være helt forfaldent. I den anledning blev der i juni 1741 foretaget syn af den sønderborgske husfoged Meynardus, der dog ikke kunne give den lidt for geskæftige gartner ret. Gartnerhuset havde allerede været $\mathrm{i}$ dårlig stand ved synet 1723 , og haven var stadig stor og skøn og kunne tåle sammenligning med den sønderborgske slotshave. Andreas Hansen kunne derfor ikke få sit ønske om overtagelse af de østerholmske slotshaver opfyldt.

Men Christian Hansen, der i øvrigt havde haverne i forpagtning på livstid, var blevet gammel og svagelig, og det kom i 1740 'erne også til at sætte sit præg på haver og gartneri. Han døde sidst $\mathrm{i}$ april $1747 \mathrm{i}$ en alder af 77 år, og der skulle nu findes en afløser for ham. Allerede nogle dage efter hans død meldte Steffen Petersen sig som liebhaver. Han var født i Ketting, havde opholdt sig 18 år i Holland og kunne møde med gode anbefalinger som gartner. Han tilbød straks at forpagte de to af haverne for en årlig afgift på 15 rdlr. De skildres af ham som halvt øde, men han mente dog at kunne bringe dem i god stand igen. Rentekammeret var imidlertid interesseret $i$ enten at sælge haverne eller at bortgive dem i arveforpagtning, og de skulle derfor afhændes ved en licitation. Denne blev afholdt $i$ august 1747, og lysthaven med det gamle gartnerhus blev udbudt særskilt og de andre haver samlet. 
Steffen Petersen blev højestbydende og overtog samtlige haver ved to købekontrakter af 7. nov. 1747. For lysthaven med det forfaldne 19 fag store gartnerhus blev købesummen 149 rdlr. cour. plus en årlig afgift til Nordborg amtstue på 2 rdlr. danske croner. Steffen Petersen fik haven med omgivende stendige og hegn, med alle frugttræer, ask, el, hassel og andre buske. Stendiget skulle som hidtil vedligeholdes af de østerholmske undersåtter.

Frugt- og køkkenhaverne fik Steffen Petersen tilslag på formedelst en kontantsum pă 1100 rdlr. cour. og en årlig afgift på 4 rdlr. danske croner til Nordborg amtstue. Af købekontrakten fremgår, at haverne var omgivet dels af en ringmur og dels af et hegn, og de stødte mod øst op til slotsgraven. De må altså $\mathrm{i}$ det store og hele have ligget vest-sydvest for slottet. I købet var indbefattet frugttræerne og alle andre træer såvel $\mathrm{i}$ haver som $\mathrm{i}$ hegn. En planteskole, der var anlagt af Chr. Hansen, horte ikke med i købet, men hans arvinger skulle fjerne planterne før overtagelsen til mortensdag 1747. Stendiger og hegn skulle som hidtil vedligeholdes af de østerholmske undersåtter, men kădnernes hovtjeneste $\mathrm{i}$ haverne ophørte, og det samme var tilfældet med gartnerens ret til grasning af to køer pă ladegărdsmarken. Hermed var de østerholmske haver overgået i privateje og synes ret hurtigt at have ophørt at eksistere som haver, gartneri og planteskole.

Af andre store herregårdshaver på Nordals kan nævnes, at der på Mjelsgård 1731 var to haver med frugttræer, som dels var omgivet af et hegn af flettede grene og dels af et tjørnehegn, som de hovpligtige undersåtter måtte holde ved lige. $^{18}$

Af de omtalte planteskoler produceredes frugttraer i Nordborg og Østerholm og gavntræer på Augustgård. Men der må dog være sket en ændring her siden i 1700-tallet, idet Søren Abildgård i sin rejseskildring fra Nordslesvig 1775-76 omtaler adskillige planteskoler på Als med bøg og eg og i denne forbindelse nævner, at ingen bondekarl måtte gifte sig, før han havde plantet et antal træer, bøg el. eg. Han skulle være ansvarlig for, at træerne blev passet mindst tre år efter plantningen. ${ }^{19}$

Disse oplysninger kan også gå på sydalsiske planteskoler, hvoraf de bedste og kendteste var Voetmann-familiens i Sønderborg og Augustenborg. ${ }^{20}$ I Sønderborg var der foruden slotshaven også en frugthave ved ladegården. Her var der 174750 æble- og pæretræer af den bedste slags. På Rønhave var der 1747 kun en lille frugthave med nogle gamle æbletræer samt en lille blomsterhave. ${ }^{21}$ På Hjortholm pă Kegnæs nævnes 1751 en have med 66 æble-, pære- og kirsebærtræer. ${ }^{22}$ 


\section{KILDEHENVISNINGER}

1. Caroline Emilie Andersen: Grams Historie, 1926 s. 1321. Der kunne vare al god grund til for en haveinteresseret historiker at gore Gram slotspark til genstand for en nojere undersøgelse. I Gram godsarkiv findes materiale hertil.

2. Sjy Arb. 1988, s. 163 og 198.

3. Johs. Tholle i Sjy Ärb. 1927, s. 170r. E. Pontoppidan: Danske Atlats, bd. V, 1769.

4. Jargen Steen Jensen: Hertug Hans d. Yngre, 1971 s. 48 og 169.

5. Johs. Tholle i Sjy Arb. 1929, s. 100f.

6. J. Raben: Nordborg gennem 800 ars skiftende historic, 1929. s. 44.

7. LA Ab, Ketting kirkebog. Aa l, blad 63 i xerokopien.

8. Sonderhorg amtsark. nr. 191. 1669, 1731. Gammelgard I, taxationen 1669 og nr. 192. 16691774. (jammelgard II.

9. Augustenborg-grastenske godsark. nr. 74 og 75, Gammelgard hovedgard.

9i. Disse og de flg. oplysninger vedr. Nordborg slotshave stammer fra Nordborg amtsarkiv, nr. 31. 1707-72. Sager vedr. Nordborg slot, Nordborg og Augustgard ladegarde samt Nordborg kirkebog $17359 / 3$ og $173718 / 10$.

10. cand. scient. Aksel Voigt, Lojt Kirkeby har venligst hjulpet mig ved oversattelsen af de latinske plantenavne.

11. Nordborg amts kopihog 1747, 72,102 og 113 .

12. Fra Als og Sundeved, hft. 62. 1984 Nordborg s. 40.

13. Nordhorg amtsark. nr. 31, 1707-72. Sager vedr. Nordborg slot, Nordborg og Augustgard ladegarde.

13a. Nordborg kirkebog.

14. J. Raben: Anf. arb. s. 63.

15. Som 13 .

16. Nordborg amtsark. nr. 36. 1680, 1707-77. Sager vedr. (Suterholm slot og ladegard. Oplysningerne vedrorende Osterholm er almindeligvis hentet fra denne pakke.

17. Nordborg amtsark. nr. 23 1722-47. Siger vedr. embedsmand.

18. Smst. nr. 38. 1692-1767. Sager vedr. Frederikshof og Mjelsgard, Beskrivelse 16/5 1731.

19. M. Mackeprang i Sjy Àrb. 19166, s. 144f.

20. Se nermere herom i Sjy Ärb. 1929, s. 100ff.

21. Sonderborg amtsark. nr. 200, 1747 Inventarium og heskrivelse af Romhave og Sonderborg ladegard.

22. Sonderborg amtsark. nr. 193. 1710-88. Hjortholm pa Kegnas. 